\title{
Cardiopulmonary performance at rest and during exercise in seven patients with increased transradiancy of one lung ('Macleod's syndrome')
}

\author{
D. A. WARRELL, J.M. B. HUGHES, and D. Y. ROSENZWEIG \\ Department of Medicine, Royal Postgraduate Medical School, Hammersmith Hospital, London, W.12
}

\begin{abstract}
A group of seven patients with increased transradiancy of one lung included four with chronic bronchitis. The function of the two lungs combined was assessed by measurement of the lung volumes, airway resistance, and carbon monoxide uptake at rest, and by measurement of pulmonary ventilation, gas exchange, blood gases, and cardiac output at rest and during steady state exercise. The contribution of the hypertransradiant lung to the overall functional abnormalities at rest was estimated using a radioactive gas technique.

All the patients had airway obstruction. Pulmonary gas exchange was only mildly affected at rest because of equal reduction of ventilation and perfusion in the abnormal lung, but during exercise ventilation-perfusion inequality increased in some of the patients. Cardiac output was low in five patients during exercise and in four there was excessive lactate production. The greatest physiological abnormalities were seen in two of the chronic bronchitics who had abnormalities of ventilation and perfusion in both lungs.

We suggest that a pulmonary vascular abnormality resulting in reduced cardiac output, as well as ventilatory impairment due to airway obstruction, may contribute to the limited exercise capacity of these patients.
\end{abstract}

A syndrome in which one lung is more transradiant than the other has been recognized increasingly since the original reports by Madoff, Gaensler, and Strieder (1952), Swyer and James (1953), and Macleod (1954). Macleod described the following features: lessening of the radiographic markings with persistently greater transradiancy over one lung; and quietening of the breath sounds in the same lung.

Features of this syndrome which are unusual in cases of centrilobular or panacinar emphysema are the small or normal size of the affected lung, and the presence of abnormalities in the major bronchi. The bronchogram of the hypertransradiant lung often reveals distortion of the peripheral bronchioles (Brit. med. J., 1965). No single cause is sufficient to explain all the cases which have been described. Some have evidence of pulmonary artery aplasia (Belcher, Capel, Pattinson, and Smart, 1959) and in others the condition may arise after a childhood respiratory infection (Reid, Simon, Zorab, and Seidelin, 1967).

Correspondence to Dr. J. M. B. Hughes
The presence of abnormalities in one lung only makes the physiological situation in these patients an interesting one. The attribution of functional defects to the hypertransradiant lung is made difficult, however, by the presence of generalized chronic obstructive bronchitis in many of them (Brit. med. J., 1965; Nairn and Prime, 1967). Physiological studies so far reported have investigated overall function using conventional techniques and have attempted to assess the function of the lungs separately using differential bronchospirometry (Darke, Chrispin, and Snowden, 1960 ; Kent, 1964 ; Belcher et al., 1959 ; Dornhorst, Heaf, and Semple, 1957) or radioactive gas techniques (Nairn and Prime, 1967).

Since effort intolerance is the commonest symptom among patients with this syndrome, we have studied the combined function of the two lungs both at rest and during submaximal exercise and have also measured differential function of the lungs using a radioactive gas technique (xenon-133). The results of the two approaches are compared in an attempt to assess the effect of the function of the hypertransradiant and 
'normal' lung on overall cardiopulmonary performance.

\section{PATIENTS AND METHODS}

Seven male patients who satisfied the radiological and clinical criteria detailed above (Macleod, 1954) were selected for the study. The Medical Research Council Questionnaire on Respiratory Symptoms (1966) was completed for each patient using the instructions of the M.R.C. Committees $(1960 ; 1966)$.

\section{TESTS OF OVERALL CARDIORESPIRATORY FUNCTION}

Lung mechanics Forced expired volume in the first second $\left(\mathrm{FEV}_{1}\right)$ and vital capacity (VC) were measured with a McDermott bellows spirometer. Specific airway conductance (SGaw), functional residual capacity (FRC), residual volume (RV), and total lung capacity (TLC) were calculated from measurements made in a whole body plethysmograph (Guyatt, Alpers, and Davies, 1967).

Carbon monoxide uptake $\left(D_{\mathrm{co}}\right)$ This was measured using a single-breath method (Ogilvie, Forster, Blakemore, and Morton, 1957). A simultaneous measurement of alveolar volume $\left(V_{A}\right)$ by helium dilution allowed calculation of the diffusion constant $\left(\mathrm{D}_{\mathrm{co}} / \mathrm{V}_{\mathrm{A}}\right)$.

Exercise tests The patients sat in an upright position on the Elema electrically stabilized load bicycle ergometer. Exercise capacity was assessed by a preliminary study in which the load was increased by 100 kilopondmetres per minute each minute until the patients were unable to continue. Power loads well within this capacity were chosen for the steady state exercise test.

The respiratory circuit has been described elsewhere (Jones, McHardy, Naimark, and Campbell, 1966). Expired gas was passed into the Tissot spirometer, which served as a mixing chamber except during the timed collections. Expired gas was sampled either at the mouth (tidal gas) or beyond the Tissot spirometer (mixed expired gas), and was analysed by an infrared $\mathrm{CO}_{2}$ meter (Godart URAS) and a paramagnetic $\mathrm{O}_{2}$ meter (Servomex DCL). Heart rate was calculated from the continuous electrocardiograph (ECG) record. Electrical outputs were from a potentiometer which recorded volume changes in the Tissot spirometer, and a $\mathrm{CO}_{2}$ meter, and ECGs were displayed on a direct writing recorder (Mingograf 81). Oxygenated mixed venous $\mathrm{PCO}_{2}\left(\mathrm{P}_{\bar{v}} \mathrm{CO}_{2}\right)$ was measured by a rebreathing method (Jones, Campbell, McHardy, Higgs, and Clode, 1967).

A PE60 catheter, $22 \mathrm{~cm}$. long, was introduced into the brachial artery using the Seldinger percutaneous technique. Blood samples were drawn anaerobically into heparinized syringes and were analysed immediately for $\mathrm{PCO}_{2}$ (Severinghaus electrode), $\mathrm{PO}_{2}$ (Beckman macroelectrode) and total plasma $\mathrm{CO}_{2}$ content (Natelson micro Van Slyke apparatus).
Oxygenated mixed venous to arterial $\mathrm{CO}_{2}$ content difference $\left(\mathrm{C} \overline{\mathrm{v}}-\mathrm{aCO}_{2}\right)$ was obtained from mixed venous to arterial $\mathrm{PCO}_{2}$ difference $\left(\mathrm{P} \overline{\mathrm{v}}-\mathrm{aCO}_{2}\right)$ using relations developed by McHardy (1967). Cardiac output was then calculated by an indirect Fick method for $\mathrm{CO}_{2}$ which has been compared with indicator dilution techniques by Higgs, Clode, McHardy, Jones, and Campbell (1967).

Arterial lactate concentration was estimated by an enzyme technique (Hohorst, 1956-7) in samples which had been drawn rapidly and immediately deproteinized with $5 \% \mathrm{w} / \mathrm{v}$ perchloric acid and refrigerated. The accuracy of all these estimations in our laboratory has been quoted by Hughes, Clode, Edwards, Goodwin, and Jones (1968b).

At rest expired gas was collected for three minutes and, simultaneously, arterial blood was sampled. Ventilation, gas exchange, blood gases, and lactate concentration were estimated. The patients then exercised at one or two work-loads. 'Steady state', as defined by Jones et al. (1966), was recognized by stability of the heart rate and end tidal and mixed expired gas concentrations. It was generally achieved by the end of the third minute of exercise. Simultaneous collection of expired gas and arterial blood for one minute was followed immediately by the measurement of $\mathrm{P}_{\bar{v}} \mathrm{CO}_{2}$. The sample for lactate estimation was taken at six minutes. Exercise was then stopped or continued at the higher work-load without a break.

Finally, the patients breathed $100 \%$ oxygen for half an hour to allow the calculation of residual or anatomical right-to-left shunt from the 'ideal' alveolar to arterial $\mathbf{P O}_{2}$ difference $\left(\mathbf{P}_{\mathbf{A}}-\mathbf{a O}_{2}\right)$.

TESTS OF Regional LUNG fUNCtion Performance of the lungs individually was assessed at rest with a radioactive gas technique using xenon-133 $\left({ }^{133} \mathrm{Xe}\right)$. The methods (West, 1966) and the results in normal subjects (Hughes, Glazier, Maloney, and West, 1968a) and in patients with chronic airway obstruction (Pain, Glazier, Simon, and West, 1967) have been previously described and only a brief description of the technique will be given.

Subjects sat upright during the studies. They first breathed room air through a mouthpiece and valve and, after a brief pause at functional residual capacity, were connected to a spirometer containing ${ }^{133} \mathrm{Xe}$. They inspired rapidly to total lung capacity (TLC) and held their breath for 12 to 15 seconds while both lungs were scanned with two pairs of scintillation counters connected in parallel over the front and back of each lung. After washout of radioactivity, the counters were held stationary over the mid-zones of the lungs (7 to $13 \mathrm{~cm}$. below the level of the second rib anteriorly) to follow the washin of radioactive gas while subjects rebreathed ${ }^{133} \mathrm{Xe}$ in a concentration of 0.5-1 mCi/litre in closed circuit. After two minutes' normal breathing, subjects were encouraged to hyperventilate and take large breaths to assist in equilibration and complete mixing of xenon. After 3.0 to 3.75 minutes' rebreathing, the counters were lowered 
and a scan of the lungs was carried out with subjects again breath-holding at TLC. In this scan regional count rates are proportional to regional lung volume. After further scans to check the washout of radioactivity the distribution of pulmonary blood flow was studied following intravenous injections of $1.5-2.0 \mathrm{mCi}$ of ${ }^{133} \mathrm{Xe}$ dissolved in saline through a catheter whose tip was placed in a subclavian vein. The subject breathed normally from a spirometer containing air which recorded tidal volumes; on the fourth or fifth breath he paused at FRC for five seconds while the ${ }^{133} \mathrm{Xe}$ solution was injected and flushed in with saline. The lungs were then scanned after inspiration to TLC. Subsequently he breathed room air normally and a further scan was made 30 seconds later after inspiration to TLC to determine the regional clearance of radioactivity. A final scan was performed with a radioactive marker at the level of the second rib.

Counting conditions The scintillation detectors had tapering focused slit collimators. The resolution in the vertical direction (full width at half height) was $2 \cdot 25 \mathrm{~cm}$. The response of the counting field was substantially uniform across one lung but did not extend to the other. The time constant of the ratemeters was 0.2 second and the scanning speed was $2 \cdot 0-2.5 \mathrm{~cm}$./ second. The data were collected in two ways. The counts from the front and back counters over each lung were summed and passed to ratemeters to be displayed as count rates on an ultraviolet recorder with a marker pulse for every centimetre of distance travelled. Additionally, the actual number of counts and the time recorded by a scaler-timer chain were, for each $2 \mathrm{~cm}$. of distance traversed by the counters, fed into a data logger with a punch-tape output (Elliott-Automation Ltd.) and analysed by computer (Kingaby, Glazier, Hughes, Maloney, and West, 1968).

Calculations By relating the scan after inspiration or injection of ${ }^{133} \mathrm{Xe}$ to the scan following equilibration, regional ventilation and perfusion per unit lung volume was obtained. Although the lung was always scanned at TLC, the distribution of blood flow was obtained for FRC because the injected xenon reached the lung at that volume. Since a maximal inspiration of gas from FRC to TLC is scarcely normal breathing, regional ventilation was also assessed in two other ways during quiet breathing. First, the washin of radioactive gas during the rebreathing equilibration procedure was analysed for both mid-zones in a manner similar to the classical nitrogen washout method. Count rates at 10 -second intervals for the first 60 to 90 seconds were related to the final equilibration value at 3 to $3 \frac{1}{2}$ minutes. The count rates were corrected for the changing xenon concentration in the spirometer (normally 'diluted' by about 25\%) and allowance was made for ${ }^{133} \mathrm{Xe}$ dissolved in chest wall tissues in determining the true equilibration value. By placing one counter over the lower abdomen it was estimated that, after $3 \frac{1}{2}$ minutes' rebreathing, tissue xenon accounted for about $8 \%$ of the count rate. The tissue correction for the initial stages of rebreathing was negligible. The time taken for each mid-zone to reach $50 \%$ equilibration $\left(t \frac{1}{2}\right)$ was calculated. This value is inversely proportional to the average alveolar ventilation of both mid-zones though it will not give due weight to excessively slowly ventilated units. Since the difference between the equilibration count rates for both mid-zones corresponded closely (except in the case of patient 3) to the difference between the summed equilibration count rates for both lungs as a whole, we think that the $t \frac{1}{2}$ values reflect the average alveolar ventilation of one lung compared with the other. The second index of ventilation was the washout of radioactivity during 30 seconds of normal breathing following the xenon injection. This value expressed as per cent clearance of the count rate immediately following the injection reflects predominantly the ventilation of perfused tissue and, if low, suggests a reduced regional ventilation-perfusion ratio. For the same value, the effect on gas exchange would be proportional to the blood flow to that area.

We considered it of greater interest in this type of patient to compare one lung as a whole with the other rather than to emphasize differences between zones in each lung. Accordingly, the area under the ratemeter traces on the ultraviolet records was estimated by planimetry for each scan. An average of $30 \mathrm{~cm}$. lung distance was included up to $7 \mathrm{~cm}$. above the second rib. Each lung was expressed as a percentage of the total. Taking into account the collimation of the counters, this represents fairly accurately the fraction of the cardiac output, single inspiration, and postinjection clearance of radioactivity in each side of the thorax.

\section{RESULTS}

Anthropometric data from the seven patients are given in Table I. Respiratory symptoms (Table II) were assessed according to the recommendations of the M.R.C. Committee on Research into Chronic Bronchitis (1960). Five patients (1, 3, 4, 5 and 7) complained of exertional dyspnoea and four patients (4 to 7), by virtue of their persistent cough and sputum production for at least three months of the year for more than two years, fulfilled diagnostic criteria of chronic bronchitis

T A B L E I

ANTHROPOMETRIC DATA FROM SEVEN MALE PATIENTS WITH INCREASED TRANSRADIANCY OF ONE LUNG

\begin{tabular}{c|c|c|c|c}
\hline Case & $\begin{array}{c}\text { Age } \\
(\mathbf{y r})\end{array}$ & $\begin{array}{c}\text { Height } \\
(\mathbf{c m})\end{array}$ & $\begin{array}{c}\text { Weight } \\
(\mathbf{k g .})\end{array}$ & $\begin{array}{c}\text { Haemo- } \\
\text { globin } \\
(\mathbf{g .} / 100 \mathrm{ml} .)\end{array}$ \\
\cline { 2 - 4 } 1 & 25 & 184 & 77 & 16.0 \\
2 & 45 & 173 & 69 & 15.6 \\
3 & 36 & 169 & 65 & 14.3 \\
4 & 55 & 182 & 81 & 13.4 \\
5 & 53 & 169 & 63 & 14.4 \\
6 & 57 & 151 & 52 & 13.5 \\
7 & 58 & 167 & 71 & 16.5 \\
\hline
\end{tabular}


(M.R.C., 1965). Only two could remember childhood respiratory illnesses. Patient 2 had bronchitis at the age of 1 year and patient 3 had pneumonia at the age of 2 years. All but one patient (6) were cigarette smokers. All the patients had diminished breath sounds on the side of their hypertransradiant lung. The basis for our prediction of normal values is Cotes (1965).

TESTS OF FUNCTION OF THE TWO LUNGS COMBINED

Lung mechanics (Table III) In all the patients the values for $\mathrm{FEV}_{1}, \mathrm{VC}$, and $\mathrm{FEV}_{1} / \mathrm{VC}$ were less than normal and indicated airway obstruction which was particularly severe in three patients $(3,4$, and 7$)$. SGaw, which is the reciprocal of airway resistance divided by the thoracic gas volume, was normal in three of the six patients in whom it was measured $(1,2$, and 5). TLC, FRC, and RV were increased in all the patients.

Carbon monoxide uptake ( $\left.D_{c o}\right)$ (Table III) None of the values for $\mathrm{D}_{\mathrm{co}}$ was grossly abnormal, but in two patients ( 3 and 4) it was less than $70 \%$ of that predicted. Values of diffusion constant were normal or high because $\mathrm{V}_{\mathrm{A}}$ was low.

Exercise tests The maximum exercise loads achieved during the progressive test are given in Table III. These indicate reduced exercise tolerance in all but patients 1,2 , and 4 . Exercise was limited by breathlessness in all cases.

Results of submaximal exercise tests are presented in Figures 1 to 5. To allow comparison with the appropriate normal values, patients are divided into two age groups-below and above 45 years. Sources of normal data are given in the legend to each figure.

Carbon dioxide output $\left(\mathrm{V}_{\mathrm{CO}_{2}}\right)$ and oxygen uptake $\left(\bar{V}_{\mathrm{O}_{2}}\right)$ were in all cases appropriate to the external power load (Fig. 1). Respiratory exchange ratio $(\mathbf{R})$ was high at rest in some cases, suggesting overbreathing (Fig. 1). During exercise $\mathbf{R}$ values rose above normal in patients 1,4 , and 6 .

Total ventilation (VE; Fig. 2) was abnormally high during exercise in two patients (1 and 5) but in none did it approach the value for maximum breathing capacity predicted from $\mathrm{FEV}_{1}$ using the

\section{T A B L E I I}

RESPIRATORY SYMPTOMS IN SEVEN PATIENTS WITH INCREASED TRANSRADIANCY OF ONE LUNG GRADED ACCORDING TO THE MEDICAL RESEARCH COUNCIL (1960 AND 1966)

\begin{tabular}{|c|c|c|c|c|c|c|c|c|}
\hline Case & $\underset{0-2}{\text { Cough }}$ & $\underset{0-2}{\text { Sputum }}$ & $\begin{array}{c}\text { Wheeze } \\
1-5\end{array}$ & $\begin{array}{c}\text { Wheeze } \\
0-2\end{array}$ & $\begin{array}{c}\text { Recent Chest } \\
\text { Illness } \\
0-2\end{array}$ & $\begin{array}{l}\text { Childhood } \\
\text { Illness }\end{array}$ & Smoking & $\begin{array}{l}\text { Chronic } \\
\text { Bronchitis }\end{array}$ \\
\hline $\begin{array}{l}1 \\
2\end{array}$ & $\begin{array}{l}\mathbf{0} \\
\mathbf{0}\end{array}$ & $\begin{array}{l}0 \\
0\end{array}$ & $\begin{array}{l}2 \\
1\end{array}$ & $\begin{array}{l}1 \\
0\end{array}$ & $\begin{array}{l}1 \\
0\end{array}$ & Bronchitis & + & $\overline{-}$ \\
\hline 3 & 0 & 0 & 2 & 0 & 1 & Pneumonia & + & - \\
\hline $\begin{array}{l}4 \\
5 \\
6 \\
7\end{array}$ & $\begin{array}{l}2 \\
1 \\
2 \\
2\end{array}$ & $\begin{array}{l}2 \\
1 \\
2 \\
2\end{array}$ & $\begin{array}{l}2 \\
3 \\
1 \\
4\end{array}$ & $\begin{array}{l}1 \\
0 \\
0 \\
0\end{array}$ & $\begin{array}{l}0 \\
0 \\
1 \\
2\end{array}$ & $\begin{array}{c}- \\
- \\
-\end{array}$ & $\begin{array}{l}+ \\
+ \\
+\end{array}$ & $\begin{array}{l}+ \\
\dot{+} \\
+\end{array}$ \\
\hline
\end{tabular}

T A B L E I I I

LUNG VOLUMES, SPECIFIC AIRWAY CONDUCTANCE, CARBON MONOXIDE UPTAKE, AND EXERCISE CAPACITY IN SEVEN PATIENTS WITH INCREASED TRANSRADIANCY OF ONE LUNG

\begin{tabular}{|c|c|c|c|c|c|c|c|c|c|c|}
\hline Case & $\mathrm{FEV}_{1}$ (1.) & VC (1.) & $\begin{array}{l}\text { FEV } 1 / \\
\text { VC }(\%)\end{array}$ & $\begin{array}{c}\mathrm{SGaw}^{2} \\
\left(\mathrm{sec}^{-1} / \mathrm{cm}\right. \\
\left.\mathrm{H}_{2} \mathrm{O}^{-1}\right)\end{array}$ & TLC (1.) & FRC (1.) & RV (1.) & $\begin{array}{c}\text { Dco } \\
\text { (ml./mm. } \\
\text { Hg/min.) }\end{array}$ & $\begin{array}{c}\text { Diffusion } \\
\text { Constant }^{3}\end{array}$ & $\begin{array}{c}\text { Exercise } \\
\text { Capacity } \\
\text { (kpm./min.) }\end{array}$ \\
\hline $\begin{array}{l}1 \\
2 \\
3 \\
4 \\
5 \\
6 \\
7\end{array}$ & $\begin{array}{l}3.10(69) 1 \\
2.25(63) \\
1.40(38) \\
1.25(35) \\
2.10(68) \\
1.10(47) \\
0.60(21)\end{array}$ & $\begin{array}{l}5 \cdot 30(96) \\
4 \cdot 10(92) \\
2 \cdot 90(65) \\
2 \cdot 80(60) \\
3 \cdot 90(96) \\
2 \cdot 20(72) \\
2 \cdot 30(60)\end{array}$ & $\begin{array}{l}59(72) \\
55(73) \\
48(62) \\
45(63) \\
54(76) \\
50(71) \\
26(37)\end{array}$ & $\begin{array}{l}0.140 \\
0.153 \\
0.063 \\
0.039 \\
0.137 \\
0.069 \\
-\end{array}$ & $\begin{array}{l}8 \cdot 8(117) \\
6 \cdot 7(103) \\
6 \cdot 6(106) \\
9 \cdot 1(125) \\
6 \cdot 8(110) \\
6 \cdot 6(143) \\
-\end{array}$ & $\begin{array}{l}5 \cdot 1(124) \\
4 \cdot 1(111) \\
4 \cdot 7(130) \\
7 \cdot 4(181) \\
4 \cdot 5(115) \\
5 \cdot 2(153) \\
-\end{array}$ & $\begin{array}{l}3.5(184) \\
2.6(137) \\
3.7(206) \\
6.3(252) \\
2.9(145) \\
4.4(266) \\
\quad-\end{array}$ & $\begin{array}{l}35.0(92) \\
28 \cdot 1(97) \\
29.5(105) \\
18.6(61) \\
20.0(73) \\
16.9(79) \\
17.1(80)\end{array}$ & $\begin{array}{l}6 \cdot 3 \\
5 \cdot 8 \\
5 \cdot 6 \\
4 \cdot 9 \\
4 \cdot 9 \\
4 \cdot 0 \\
4 \cdot 8\end{array}$ & $\begin{array}{r}1,000 \\
900 \\
600 \\
800 \\
600 \\
600 \\
50\end{array}$ \\
\hline $\begin{array}{l}\text { Means } \\
( \pm 1 \text { SE) }\end{array}$ & $\begin{array}{c}1.69 \pm \\
0.32\end{array}$ & $\begin{array}{c}3.36 \pm \\
0.43\end{array}$ & $48 \pm 4$ & $\begin{array}{c}0 \cdot 100 \pm \\
0.020\end{array}$ & $7 \cdot 4 \pm 0 \cdot 5$ & $5 \cdot 2 \pm 0.5$ & $3 \cdot 9 \pm 0.5$ & $23 \cdot 6 \pm 0.5$ & $5 \cdot 2 \pm 0 \cdot 3$ & $650 \pm 120$ \\
\hline
\end{tabular}

1 Values in brackets are \% predicted normal (Cotes, 1965)

2 Normal range 0.130-0.350 (Briscoe and Du Bois, 1958)

3 Normal range $3 \cdot 5-4 \cdot 5$ (Cotes, 1965) 


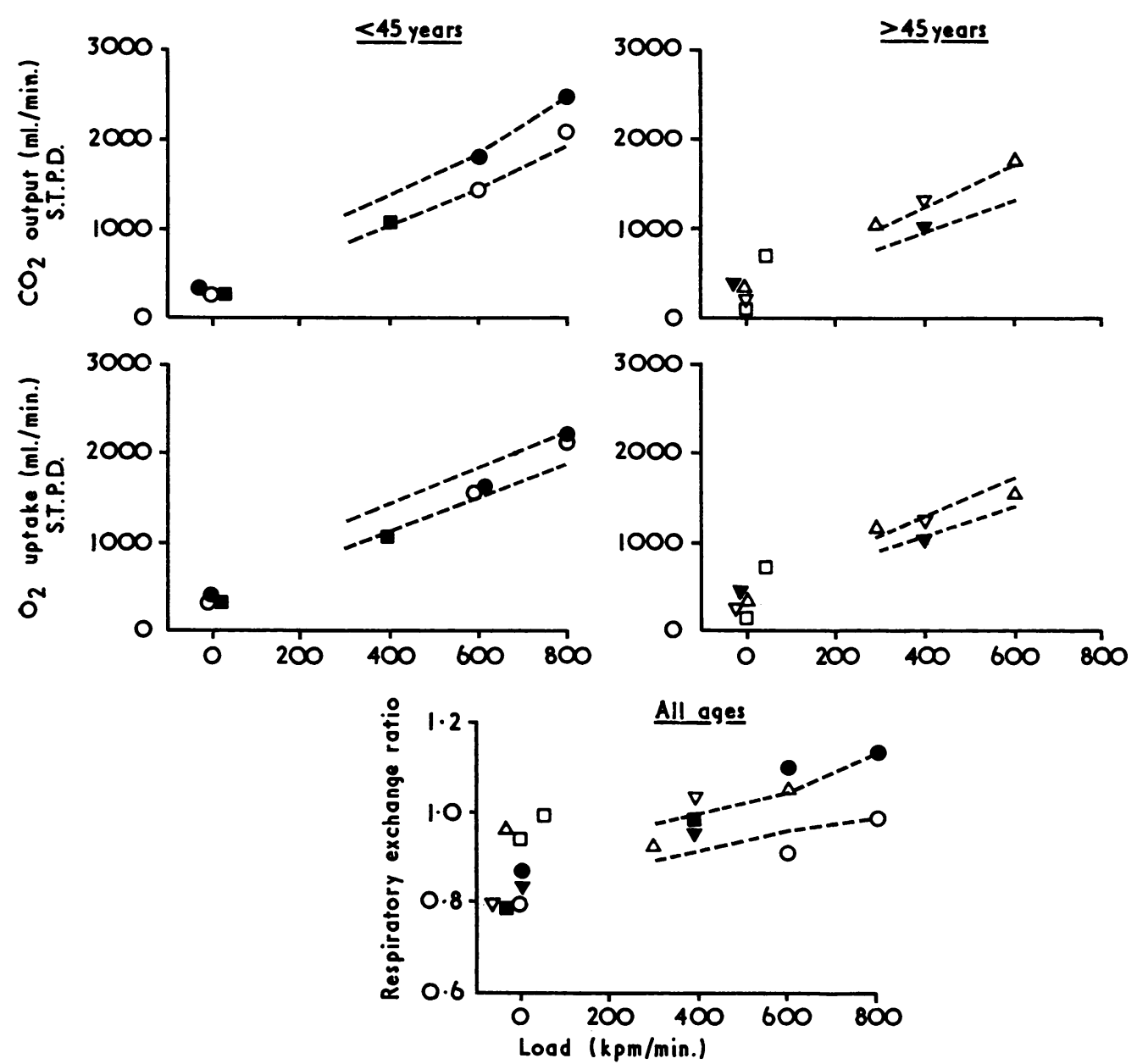

FIG. 1. Overall pulmonary gas exchange in seven patients with increased transradiancy of one lung. Key: Each patient is represented by a different symbol. Patient 1 (Table $I)=0,2=0,3=\mathbf{\square}, 4=\Delta, 5=\nabla$, $6=\nabla, 7=\square$. Normal range ( $\pm 1 S D$ of the mean) indicated by dashed lines. Source of normal data: Higgs et al. (1967).

regression equation of Clark, Freedman, Campbell, and Winn (1969). Respiratory frequency (f) was high in most cases and tidal volumes $\left(\mathrm{V}_{\mathrm{T}}\right)$ were low (Fig. 2). Physiological dead space/tidal volume ratio $\left(\mathbf{V}_{\mathbf{D}} / \mathbf{V}_{\mathbf{T}}\right)$ was abnormally high during exercise in four patients (Fig. 3).

Arterial $\mathbf{P}_{\mathrm{CO}_{2}}\left(\mathrm{PaCO}_{2}\right)$ was high at rest in patient 7 (Fig. 3). There was an abnormal rise in $\mathbf{P} \overline{\mathbf{v}}_{\mathrm{CO}_{2}}$ during exercise in patients $1,4,6$, and 7 . There was a variable fall in bicarbonate and rise in hydrogen ion concentration on exercise.

Resting arterial $\mathrm{PO}_{2}\left(\mathrm{PaO}_{2}\right)$ ranged from 58 to $83 \mathrm{~mm}$. Hg (Fig. 3), which corresponded to a saturation of 83 to $96 \% \cdot \mathrm{P}_{\mathrm{A}-\mathrm{a}_{2}}$ at rest was generally high, ranging from 22 to $44 \mathrm{~mm}$. $\mathrm{Hg}$. On exercise $\mathrm{Pa}_{\mathrm{O} 2}$ fell by 5.5 and $14 \mathrm{~mm}$. $\mathrm{Hg}$ in two patients ( 3 and 4) and rose by $8 \mathrm{~mm}$. $\mathrm{Hg}$ in one (6). Calculated $\mathrm{Sa}_{2}$ fell by more than $5 \%$ in only one patient (4). $P_{A}-a_{O 2}$ increased by 5 to $10 \mathrm{~mm}$. $\mathrm{Hg}$ in three patients $(1,3$, and 4$)$ and decreased by 3 to $8 \mathrm{~mm}$. $\mathrm{Hg}$ in three $(2,5$, and 6$)$.

Pulmonary venous admixture $\left(\mathrm{Q}_{\mathrm{r \Delta}} / \mathrm{Qt}\right)$ was high at rest in all the patients: the values ranged from 6 to $28 \%$ (Fig. 3). The residual or anatomical shunt while breathing $100 \%$ oxygen was 3 to $6 \%$ of cardiac output. During exercise $\mathrm{Q}_{\mathrm{vA}} / \mathrm{Qt}^{\mathrm{t}}$ decreased in two patients (6 and 7) and increased in two ( 3 and 4$)$. 


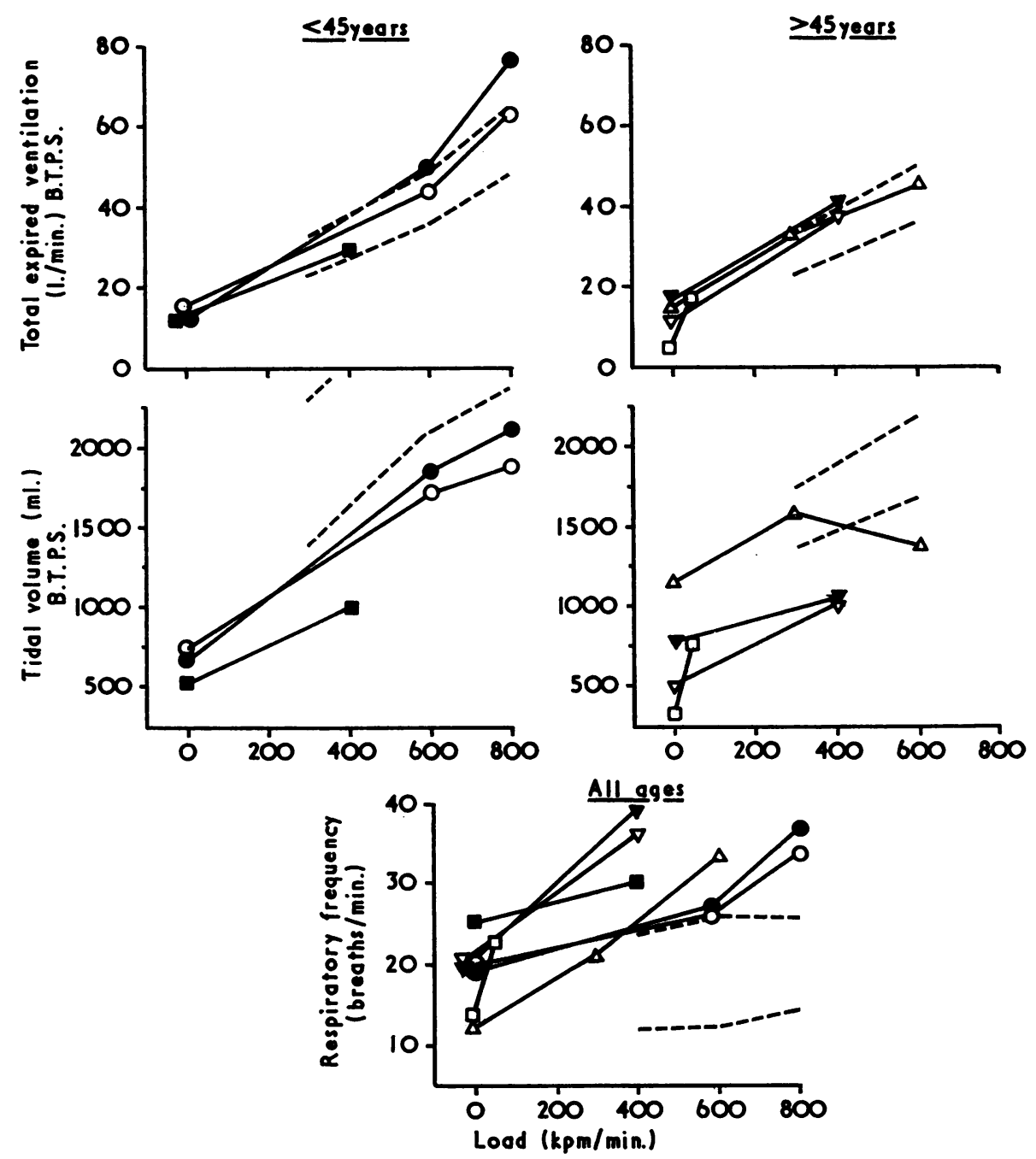

FIG. 2. Pulmonary ventilation in seven patients with increased transradiancy of one lung. Key as in Fig 1. Source of normal data: Higgs et al. (1967).

Cardiac output was abnormally low during exercise in five patients $(1,2,4,6$, and 7$)$ (Fig. 4). Heart rates were excessive, especially at the highest work-load, in all but two patients. In all cases calculated stroke volume was low.

Arterial lactate concentration (Fig. 5) rose excessively during exercise in four out of six patients $(1,3,4$, and 6$)$.

TESTS OF FUNCTION OF THE TWO LUNGS SEPARATELY

Table IV shows the distribution of perfusion and ventilation to each lung in the seven patients. The more normal lung received $75 \%$ of the cardiac output. The ventilation indices all gave different ratios. The ventilation of the normal to the abnormal lung was $1.6: 1$ on a single large inspiration but the average alveolar ventilation ratio during quiet breathing was about $3 \cdot 7: 1$. In the perfused areas the ventilation ratio was $1 \cdot 4: 1$.

We regard $80 \%$ as the lower limit of normal for $Q$ clearance at $\mathbf{3 0}$ seconds. All the values for the hypertransradiant lung were abnormal except possibly in case 5 . Two patients (6 and 7) had low clearance values on the 'normal' side; interestingly, case 7 had the highest measured $Q_{\mathrm{rA}} / \mathrm{Qt}$ 

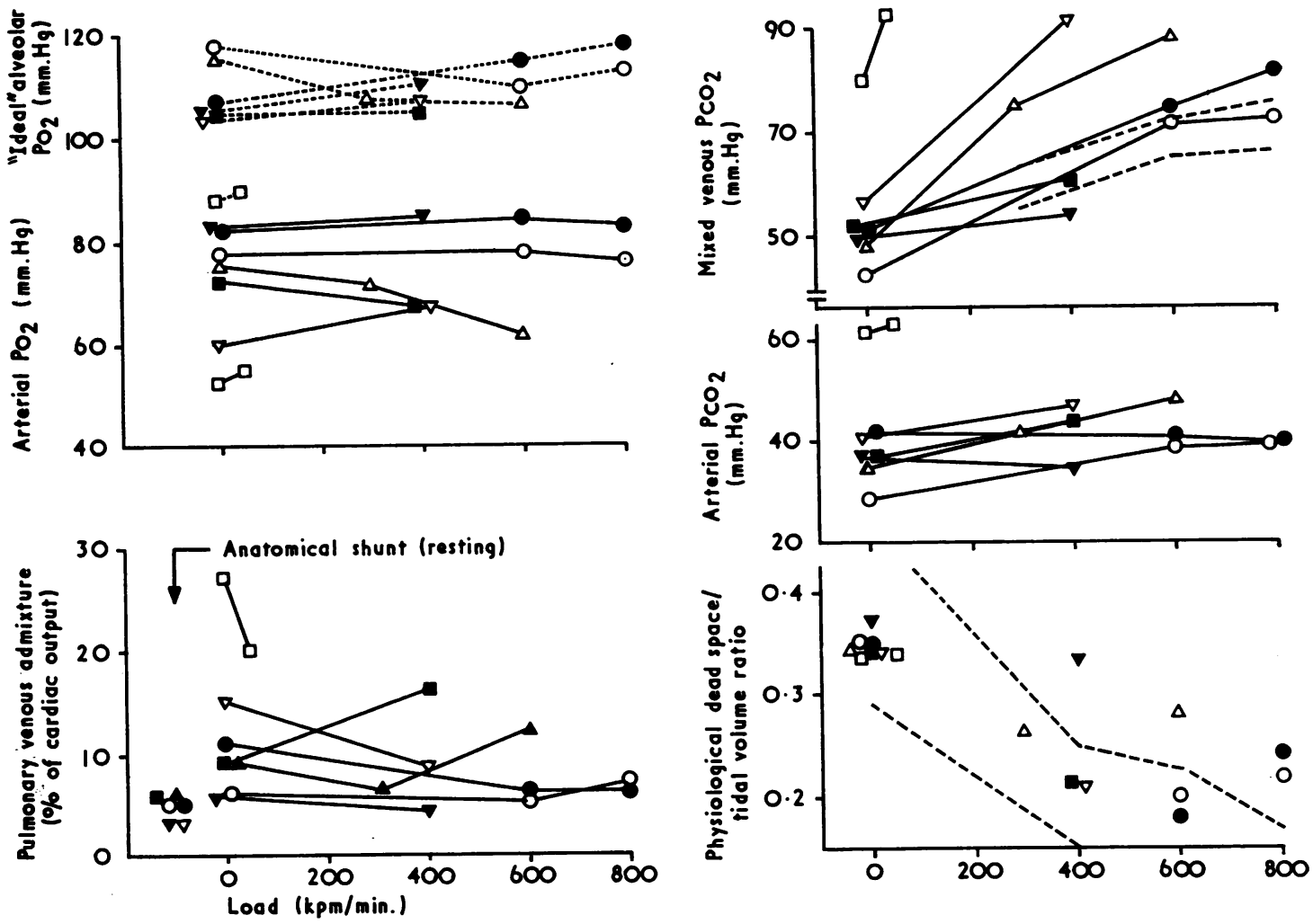

FIG. 3. Blood gas tensions, pulmonary venous admixture, and physiological dead space: tidal volume ratio in seven patients with increased transradiancy of one lung. Key as in Fig. 1. Sources of normal data: Mixed venous PCO $\mathrm{CO}_{2}$ Higgs et al. (1967). Dead space/tidal volume ratio, Edwards (1968).

T A B L E IV

DISTRIBUTION OF PERFUSION AND VENTILATION TO NORMAL (A) AND HYPERTRANSRADIANT (B) LUNGS

\begin{tabular}{|c|c|c|c|c|c|c|c|c|}
\hline \multirow{2}{*}{ Case } & \multicolumn{2}{|c|}{$\mathbf{Q} \%$} & \multicolumn{2}{|c|}{ Q Clearance $\%^{2}$} & \multicolumn{2}{|c|}{ Inspiration FRC-TLC $\%^{\mathbf{5}}$} & \multicolumn{2}{|c|}{$t_{\frac{1}{2}}(\sec .)^{3}$} \\
\hline & Lung A & Lung B & Lung A & Lung B & Lung A & Lung B & Lung $\mathbf{A}$ & Lung B \\
\hline $\begin{array}{l}1 \\
2 \\
3 \\
4 \\
5 \\
6 \\
7\end{array}$ & $\begin{array}{l}74 \\
86 \\
90 \\
71 \\
64 \\
71 \\
77\end{array}$ & $\begin{array}{l}26(\mathrm{R})^{4} \\
14(\mathrm{~L}) \\
10(\mathrm{~L}) \\
29(\mathrm{R}) \\
36(\mathrm{R}) \\
29(\mathrm{~L}) \\
23(\mathrm{~L})\end{array}$ & $\begin{array}{l}90 \\
95 \\
81 \\
82 \\
93 \\
71 \\
75\end{array}$ & $\begin{array}{l}52 \\
57 \\
68 \\
42 \\
79 \\
60 \\
56\end{array}$ & $\begin{array}{l}53 \\
66 \\
76 \\
63 \\
49 \\
54 \\
64\end{array}$ & $\begin{array}{l}47 \\
33 \\
24 \\
37 \\
51 \\
45 \\
36\end{array}$ & $\begin{array}{l}10 \\
10 \\
17 \\
12 \\
25 \\
22 \\
38\end{array}$ & $\begin{array}{r}20 \\
50 \\
\infty \\
100 \\
60 \\
73 \\
125\end{array}$ \\
\hline
\end{tabular}

1 Distribution of pulmonary blood flow at FRC

2 Percentage radioactivity removed from each lung after intravenous ${ }^{133} \mathrm{Xe}$ injection during 30 seconds quiet breathing

Time taken for mid-zone of the lung to achieve $50 \%$ equilibrium during equilibration with ${ }^{132} \mathrm{Xe}$ gas in closed circuit

Time taken for mid-zone of the lung to achieve $50 \%$ equilibrium during equilibration

sroportion of inhaled gas per unit volume to each lung during a slow inspiration from FRC to TLC

$(27 \%)$ at rest and case 6 the largest resting $V_{D} / V_{T}$ $(0.42)$. There were significant abnormalities in regional distribution within the normal lung, all of which were in the lower zone, in three patients. Case 4 had less basal ventilation than apical, and cases 6 and 7 had reduced basal ventilation and perfusion relative to the mid and upper zones. In the abnormal lung all had widespread abnormalities of ventilation and perfusion, but these were always more marked in the lower zones. 

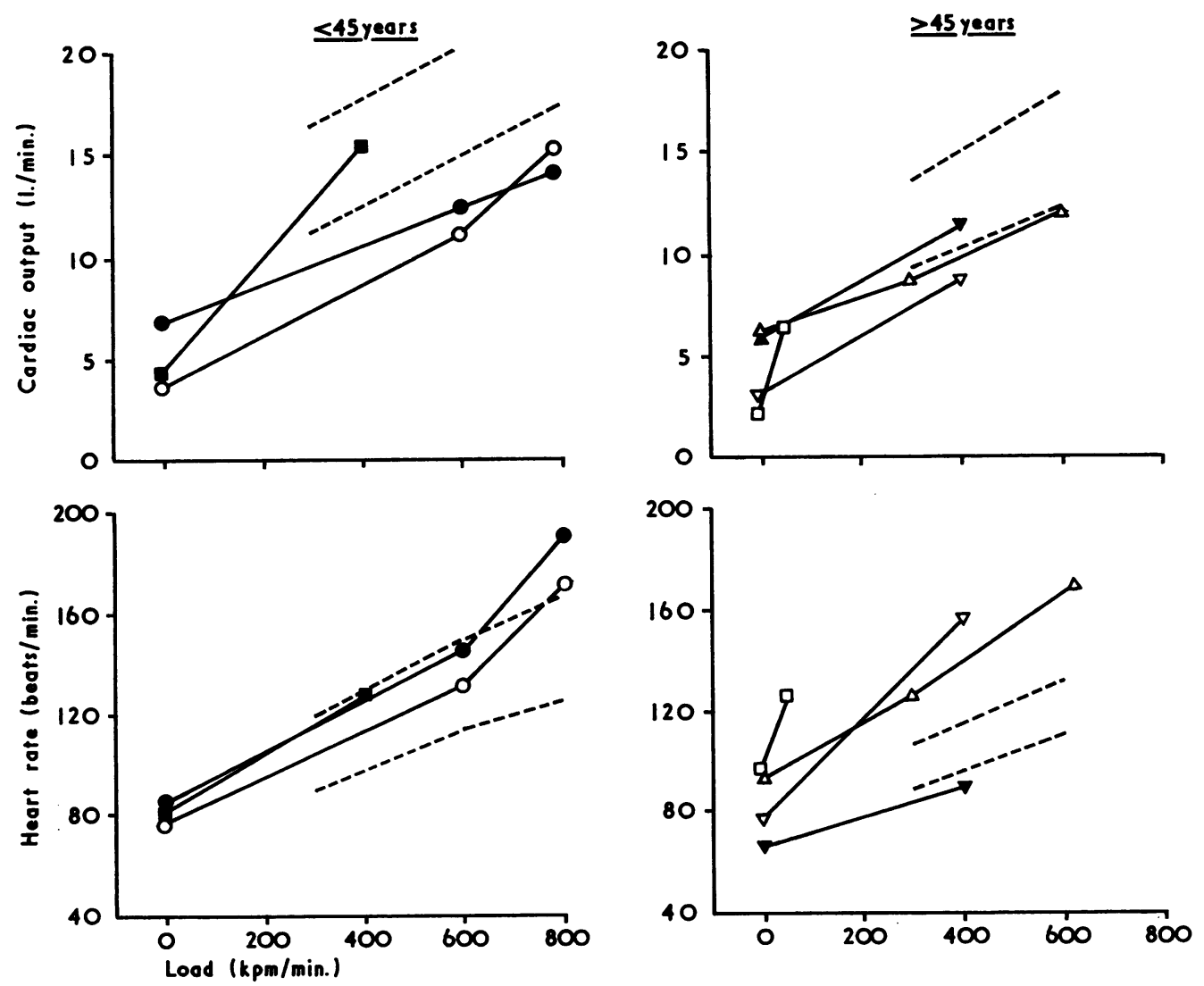

FIG. 4. Cardiac output and heart rate in seven patients with increased transradiancy of one lung. Key as in Fig. 1. Source of normal data: Higgs et al. (1967).
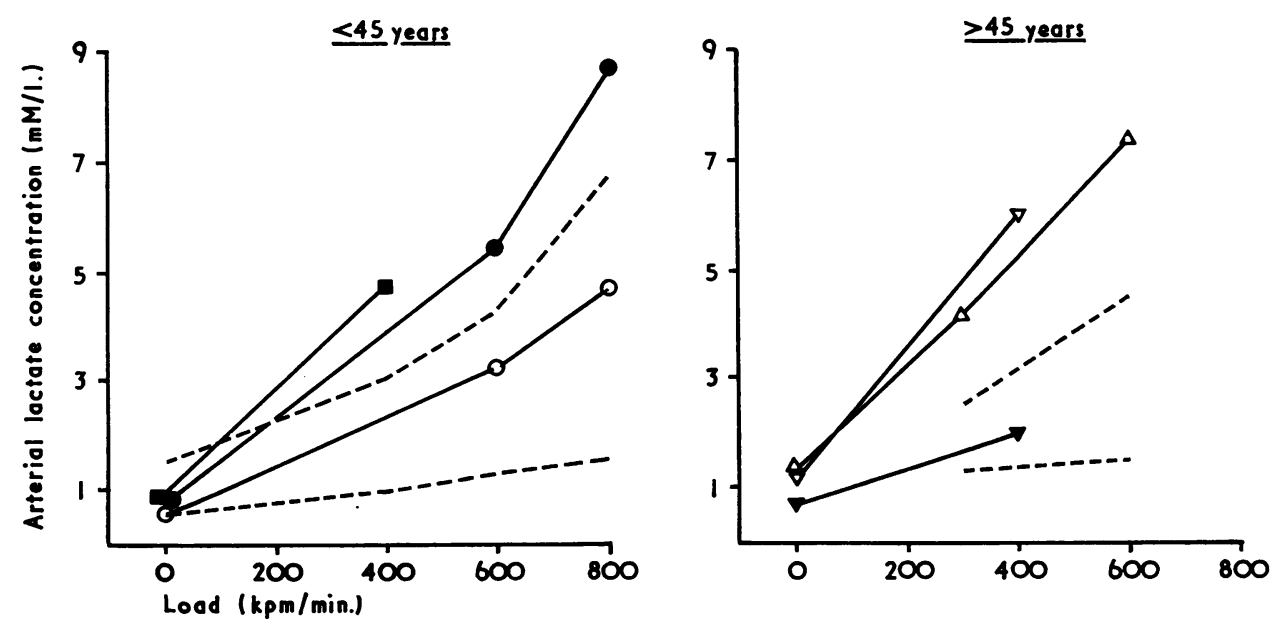

FIG. 5. Arterial lactate concentration in seven patients with increased transradiancy of one lung. Key as in Fig. 1. Sources of normal data: < 45 years, Clode (1967); > 45 years, Strandell (1964). 


\section{DISCUSSION}

Differential tests of lung function indicated that in four of the patients in the study (cases 1 to 4 , Table IV) the unaffected lung was relatively well ventilated and perfused $\left(t \frac{1}{2}<20\right.$ sec., $Q$ clearance $>80 \%$ ) whereas in the other three patients (cases 5 to 7) there were $V / Q$ abnormalities in both lungs ( $t \frac{1}{2}>20$ sec., $Q$ clearance $<80 \%$ ). From the functional viewpoint, we have divided the cases into these two groups: patients 1 to 4 (group I) with abnormalities of one lung only and lacking (except for case 4) the symptoms of bronchitis, and patients 5 to 7 (group II) where regional measurements showed both lungs to be functionally abnormal.

Table $V$ summarizes some of the differences between the two groups; exceptions to this simplification are indicated. The three patients in group II all had chronic bronchitis which was probably the cause of the $V / Q$ abnormalities in their normally transradiant lung. All seven patients had arterial hypoxaemia at rest. The high values for $\mathrm{PA}_{\mathrm{A}}-\mathrm{aO}_{2}$ and $\mathrm{Q}_{\mathrm{VA}} / \mathrm{Qt}$ while breathing air and the small shunt while breathing $100 \%$ oxygen indicate that impaired pulmonary oxygen uptake attributable to $V / Q$ abnormalities was the cause of hypoxaemia.

\section{T A B L E V}

SUMMARY OF PRINCIPAL DIFFERENCES BETWEEN THE TWO GROUPS OF PATIENTS WITH INCREASED TRANS-

\begin{tabular}{|c|c|c|}
\hline & Group I & Group II \\
\hline Patient numbers & $1-4$ & $5-7$ \\
\hline Chronic bronchitis & Absent (except 4) & Present \\
\hline $\begin{array}{l}\text { At rest } \\
\text { Regional } \\
\text { abnormalities } \\
\text { Hypoxaemia }\end{array}$ & $\begin{array}{l}\text { Unilateral } \\
\text { Mild }\end{array}$ & $\begin{array}{l}\text { Bilateral } \\
\text { Severe } \\
\quad \text { (except 5) }\end{array}$ \\
\hline $\begin{array}{l}\text { Exercise capacity } \\
\text { Arterial } \mathbf{P o}_{2}\end{array}$ & $\begin{array}{l}\text { Normal (except 3) } \\
\text { Unchanged/ }\end{array}$ & $\begin{array}{l}\text { Reduced } \\
\text { Increased }\end{array}$ \\
\hline $\begin{array}{l}\text { Pulmonary venous } \\
\text { admixture }\end{array}$ & Increased (except 1) & Decreased \\
\hline
\end{tabular}

In group $I$, these $V / Q$ abnormalities were confined to the hypertransradiant lung. $\mathrm{Pa}_{2}$ was lower in patients 3 and 4 than in patients 1 and 2. This was probably explained by the very poor distribution of alveolar ventilation in patients 3 and 4 shown by $t \frac{1}{2}$ values of $\infty$ and 100 seconds respectively compared with 20 and 40 seconds in patients 1 and 2 . Dco was normal in patients 1 ,
2 , and 3 , but clearly reduced in patient 4 (Table III). In group II, patient 5 showed only slight evidence of impaired pulmonary gas exchange. This was explained by the observation that $Q$ clearance was normal in both lungs, which suggests that perfused tissue was well ventilated. Patients 6 and 7 showed the worst degree of impaired pulmonary gas exchange: $\mathrm{PaO}_{2}$ was below $60 \mathrm{~mm}$. $\mathrm{Hg}$ and $\mathrm{Q}_{\mathrm{vA}} / \mathrm{Qt}$ was 15 and $27 \%$. This was consistent with the finding of strikingly reduced $Q$ clearance and prolonged $t \frac{1}{2}$ in both lungs (Table IV). Single breath $D_{\text {co }}$ was relatively less reduced than in patients 4 and 5 despite the greater degree of arterial hypoxaemia at rest in patients 6 and 7. In this respect the latter resemble Jones's (1966) type B patients. The apparent paradox is explained by the fact that the breathholding involved in the single breath $D_{c o}$ measurement creates a more even distribution of $V / Q$ in these patients. During exercise $\mathrm{Pa}_{2}$ decreased and $Q_{\mathrm{r} \Delta} / \mathrm{Qt}_{\mathrm{t}}$ increased in patients 3 and 4, suggesting increased $V / Q$ imbalance in their hypertransradiant lung. In this respect they resembled the patients with severe emphysema (type A) studied by Jones (1966), whereas the patients in group II showed increased $\mathrm{PaO}_{2}$ and decreased $\mathrm{Q}_{\mathrm{VA}} / \mathrm{Qt}$ during exercise, suggesting more even distribution of $V / Q$ as in patients with severe obstructive bronchitis (type B). It appears that the increase in overall alveolar ventilation and pulmonary blood flow during exercise in the group I patients could not improve the $V / Q$ distribution and hence pulmonary gas exchange. The patients in group II showed greater physiological abnormalities attributable to the development of obstructive bronchitis in both lungs. Improved $\mathbf{V} / Q$ distribution during exercise was presumably the cause of the observed improvement in their pulmonary gas exchange, but this remained more abnormal than in the patients in group I.

Considering the seven patients together some general points emerge. At rest ventilation and perfusion were about equally reduced in the hypertransradiant lung; as a result pulmonary oxygen exchange was preserved to some extent. Thus the mean distribution of $\mathrm{Q} \%$ to the normal and abnormal lungs was $3: 1$, and of 'average' ventilation (assessed by $t \frac{1}{2}$ ) was $3 \cdot 7: 1$. In the series described by Nairn and Prime (1967) there was also a $75 \%$ distribution of perfusion to the normal lung. These authors estimated a distribution of $67 \%$ of total alveolar ventilation to the normal lung; using measurements of $t \frac{1}{2}$ we estimate $80 \%$. The only two patients in whom this compensation' of $\vec{V}$ and $Q$ did not seem to be effective were 
cases 6 and 7, both chronic bronchitics with bilateral abnormalities of ventilation and perfusion. During exercise $V / Q$ relationship changed in a manner which varied from patient to patient. In some patients increases in $V_{D} / V_{T}$ (cases 1,2 , 4 , and 5) or $Q_{\mathrm{vA}} / \mathrm{Qt}$ (cases 3 and 4) suggest a less effective distribution of ventilation with respect to perfusion, whereas in others $\mathrm{Q}_{\mathrm{vA}} / \mathrm{Qt}$ decreased (cases 6 and 7), suggesting improved ventilation of perfused areas of the lung.

We have attempted to explain the degree of impairment of exercise tolerance in these patients by the observed cardiorespiratory abnormalities. Thus the severity of airways obstruction in cases 3 and 7 may explain why their exercise tolerance was more limited than in other patients in their particular groups. Breathlessness was the commonest symptom to limit progressive exercise, but in most cases it seems unlikely that pulmonary ventilation was the major limiting factor, for at the maximum load achieved heart rates were generally excessive and nearing their predicted maxima, yet total ventilation did not nearly approach sustained maximal voluntary ventilation calculated from $\mathrm{FEV}_{1}$ (Clark et al., 1969).

The generally excessive heart rate response and the low cardiac output in five out of seven patients (cases 1, 2, 4, 6, and 7) suggests that a circulatory factor may have contributed to the limitation of exercise tolerance. In patients 1, 3, 4, and 6 there was an excessive lactic acidaemia during exercise indicative of increased anaerobic metabolism. Possible causes include low cardiac output in patients 1, 4, and 6, hypoxaemia, especially in patient 4 , and inadequate distribution of blood flow to the exercising muscles as is envisaged in the state of 'unfitness'. In the patients with subnormal cardiac outputs during exercise a low proportion of cardiac output at rest went to the hypertransradiant lung (14 to $29 \%$ ) and ventilation of perfused tissue was reduced ( $Q$ clearances were 42 to $60 \%$ ). In case 5 , who had a normal cardiac output at $400 \mathrm{kpm}$./min., the hypertransradiant lung had a larger share $(36 \%)$ of the total cardiac output than in any of the other patients, and this perfused tissue was well ventilated $(Q$ clearance was $79 \%$ ). In case 3 , who also had a normal cardiac output at $400 \mathrm{kpm}$./min., a very low proportion of the cardiac output went to the hypertransradiant lung, but the perfused tissue was relatively well ventilated (Q clearance $68 \%$ ).

Pulmonary angiography was not considered to be justified in any of our patients. Pulmonary vascular anomalies have often been described in patients with increased transradiancy of one lung
(Belcher et al., 1959) and some authors attribute the syndrome to congenital hypoplasia of a pulmonary artery. Development of pulmonary blood vessels may be impaired in those patients thought to have acquired the syndrome as the result of a childhood respiratory infection (Reid et al., 1967).

Reduced cardiac output response to exercise has been reported in several conditions which reduce the size of the pulmonary vascular bed. Thus De Graff, Taylor, Ord, Chuang, and Johnson (1965) and Linderholm (1959) found evidence of reduced maximal cardiac outputs in patients after massive pulmonary resection and considered this to be the principal limitation to maximal oxygen uptake. Wilhelmsen, Selander, Söderholm, Paulin, Varnauskas, and Werkö (1963) found that the arteriovenous oxygen content difference increased during exercise (to 6.2 and $12.2 \mathrm{ml} . / 100 \mathrm{ml}$.) in two patients with recurrent pulmonary embolism, implying that cardiac output was inadequate. We suggest that in some patients with increased transradiancy of one lung, low cardiac output, resulting from a pulmonary vascular abnormality in the hypertransradiant lung, may impose a circulatory limitation on exercise capacity as important as the ventilatory limitation resulting from their airway obstruction. The pulmonary vascular bed may be considered a system of parallel channels whose patency is determined by the relationship between pulmonary artery pressure and the critical opening pressures of individual channels (Permutt, 1969). At rest a variable number of channels is closed but during exercise the increase in pulmonary artery pressure eventually opens all the channels and a certain relationship between pressure and flow will then exist. If the number of channels is restricted this relationship must be altered so that a higher pressure is required to maintain the same flow (West and Dollery, 1965). An elevated pulmonary artery pressure, acting reflexly or directly on the right ventricle, might be expected to reduce cardiac output in these circumstances. In the two patients with recurrent pulmonary embolism studied by Wilhelmsen et al. (1963), a low cardiac output during exercise was associated with high pulmonary arterial pressure. The reduced vascular bed and pulmonary blood volume in patients with unilateral hypertransradiancy could in this way result in a limitation of cardiac output during exercise which would contribute to effort intolerance.

We are grateful to Miss Helen M. Pope, Miss R. Ann Hart, and Miss Prisca Chong for technical help. 


\section{REFERENCES}

Belcher, J. R., Capel, L., Pattinson, J. N., and Smart, J. (1959) Hypoplasia of the pulmonary arteries. Brit. J. Dis. Chest, 53 , 253.

Briscoe, W. A., and Du Bois, A. B. (1958). The relationship between airway resistance, airway conductance and lung volume in subjects of different age and body size. J. clin. Invest., 37, 1279.

British Medical Journal (1965). Clinicopathological Conference. A case of chronic bronchitis with Macleod's syndrome. Brit. med. J., 1, 708.

Clark, T. J. H., Freedman, S., Campbell, E. J. M., and Winn, R. R. (1969). The ventilatory capacity of patients with chronic airways obstruction. Clin. Sci., 36, 307.

Clode, M. (1967). $\mathrm{CO}_{2}$ production and excretion during exercise. Ph.D. thesis, University of London.

Cotes, J. E. (1965). Lung Function. Blackwell Scientific Publications, Oxford.

Darke, C. S., Chrispin, A. R., and Snowden, B. S. (1960). Unilateral lung transradiancy: a physiological study. Thorax, 15, 74

De Graff, A. C., Taylor, H. F., Ord, J. W., Chuang, T. H., and Johnson, R. L. (1965). Exercise limitation following extensive pulmonary resection. J. clin. Invest., 44, 1514.

Dornhorst, A. C., Heaf, P. J., and Semple, S. J. G. (1957). Unilateral 'emphysema'. Lancet, $2,873$.

Edwards, R. H. T. (1968). Personal communication.

Guyatt, A. R., Alpers, J. H., and Davies, E. E. (1967). Design of body plethysmograph for use in field studies. J. appl. Physiol. 22, 390 .

Higgs, B. E., Clode, M., McHardy, G. J. R., Jones, N. L., and Campbell, E. J. M. (1967). Changes in ventilation, gas exchange and

Hohorst, H. J. (1956-7). Enzymatische Bestimmung von L (+)Milchsäure. Biochem. Z., 328, 509.

Hughes, J. M. B., Glazier, J. B., Maloney, J. E., and West, J. B. (1968a). Effect of lung volume on the distribution of pulmonary blood flow in man. Resp. Physiol., 4, 58.

Hughes, R. L., Clode, M., Edwards, R. H. T., Goodwin, T. J., and Jones, N. L. (1968b). Effect of inspired $\mathrm{O}_{2}$ on cardiopulmonary and metabolic responses to exercise in man. J. appl. Physiol., 24, 336.

Jones, N. L. (1966). Pulmonary gas exchange during exercise in patients with chronic airway obstruction. Clin. Sci., 31, 39. Campbell, E. J. M., McHardy, G. J. R., Higgs, B. E., and Clode, M. (1967). The estimation of carbon dioxide pressure of mixed venous blood during exercise. Clin. Sci., 32, 311.

- McHardy, G. J. R., Naimark, A., and Campbell, E. J. M. (1966). Physiological dead space and alveolar-arterial gas pressure differences during exercise. Clin. Sci., 31, 19.

Kent, D. C. (1964). Physiologic aspects of idiopathic unilateral hyperlucent lung. Amer. Rev. resp. Dis., 90, 202.
Kingaby, G. P., Glazier, J. B., Hughes, J. M. B., Maloney, J. E., and West, J. B. (1968). Automation of data collection and analysis in lung scanning with radioactive gases. Med. Biol. Engng, 6, 403.

Linderholm, H. (1959). Diffusing capacity of the lungs as a limiting factor for physical working capacity. Acta med. scand., 163, 61 .

McHardy, G. J. R. (1967). The relationship between the differences in pressure and content of carbon dioxide in arterial and venous blood. Clin. Sci., 32, 299.

Macleod, W. M. (1954). Abnormal transradiancy of one lung. Thorax, 9, 147.

Madoff, I. M., Gaensler, E. A., and Strieder, J. W. (1952). Congenital absence of the right pulmonary artery. Diagnosis by angiocardiography, with cardiorespiratory studies. New Engl. J. Med., 247, 149.

Medical Research Council (1960). Instructions for the Use of the Questionnaire on Respiratory Symptoms. Approved by the M.R.C. Committee on the Aetiology of Chronic Bronchitis.

Medical Research Council Committee on the Aetiology of Chronic Bronchitis (1965). Definition and classification of chronic bronchitis for clinical and epidemiological purposes. Lancet, 1, 775.

- (1966). Instructions for the use of Questionnaire on Respiratory Symptoms. Approved by the M.R.C. Committee on Research into Chronic Bronchitis.

Nairn, J. R., and Prime, F. J. (1967). A physiological study of Macleod's syndrome. Thorax, 22, 148.

Ogilvie, C. M., Forster, R. E., Blakemore, W. S., and Morton, J. W. (1957). A standardized breath holding technique for the clinical measurement of the diffusing capacity of the lung for carbon monoxide. J. clin. Invest., 36, 1 .

Pain, M. C. F., Glazier, J. B., Simon, H., and West, J. B. (1967). Regional and overall inequality of ventilation and blood flow in patients with chronic airflow obstruction. Thorax, 22, 453.

Permutt, S. (1969). Theoretical pressure-flow-volume relations of pulmonary circulation assuming indistensible vessels with a spectrum of critical opening pressures. Fed. Proc., 28, 281, No. 134.

Reid, L., Simon, G., Zorab, P. A., and Seidelin, R. (1967). The development of unilateral hypertransradiancy of the lung. Brit. J. Dis. Chest, 61, 190.

Strandell, T. (1964). Heart rate, arterial lactate concentration and oxygen uptake during exercise in old men compared with young men. Acta physiol. scand., 60, 197.

Swyer, P. R., and James, G. C. W. (1953). A case of unilateral pulmonary emphysema. Thorax, 8,133

West, J. B. (1966). Use of radioactive materials in the study of lung function. The Radiochemical Centre, Amersham, Medical Monographs, 1.

- and Dollery, C. T. (1965). Distribution of blood flow and the pressure-flow relations of the whole lung. J. appl. Physiol., 20, 175.

Wilhelmsen, L., Selander, S., Söderholm, B., Paulin, S., Varnauskas, E., and Werkö, L. (1963). Recurrent pulmonary embolism. Medicine (Baltimore), 42, 335. 